\title{
Revisiting the Relationship Between Price Regulation and Pharmaceutical R\&D Investment
}

\author{
Mujaheed Shaikh $^{1}$ (1) Pietro Del Giudice ${ }^{2} \cdot$ Dimitrios Kourouklis $^{3,4}[0$
}

Published online: 15 July 2020

(c) The Author(s) 2020

\begin{abstract}
Background A trade-off exists between affordability of pharmaceutical products today and incentives for firms to provide new and better drugs in the future; an activity that prior studies suggest correlates with profitability, which in turn depends on price regulation.

Objective In this paper we re-examined the relationship between price regulation and pharmaceutical research and development (R\&D) intensity, and explored the role of profitability and cash flow in mediating this relation using the latest available data from 2000 to 2017 for the 10 most innovative pharmaceutical companies.

Methods Following a framework similar to a previous study, we exploited stylized facts about sales volumes in Europe and USA, which give rise to variation in exposure to price regulation. Using ordinary least squares fixed effects models, we assess whether price regulation is related to R\&D investment through cash flow effects and profitability.

Results While exposure to price regulation (measured by relative market share in EU/USA) is related negatively to R\&D intensity, and this result is driven by price regulation being negatively related to cash flow and profitability, the results were not significant when firm fixed effects were added to the regression models. Modeling firm dynamics showed that cash flow and profitability of European- and US-based firms responded differently to exposure to price regulation. Thus, firm specific effects play an important role in explaining the negative relationship between price regulation and R\&D intensity. These results were robust to the inclusion of different time-varying firm level variables.

Conclusion The findings suggest that investment decisions of firms are most likely driven by long-run inter-firm differences, and that firm effects strongly determine firm strategies in terms of R\&D investment.
\end{abstract}

\section{Introduction}

Countries have enforced several forms of pharmaceutical price regulation to control rising pharmaceutical expenditures [1-3]. The main pricing mechanisms that are in

Electronic supplementary material The online version of this article (https://doi.org/10.1007/s40258-020-00601-9) contains supplementary material, which is available to authorized users.

Mujaheed Shaikh

shaikh@hertie-school.org

1 Hertie School, Friedrichstraße 180, 10117 Berlin, Germany

2 Vienna University of Economics and Business, Welthandelspl. 1, 1020 Vienna, Austria

3 Centre D'économie Industrielle (CERNA), MINES ParisTech, PSL University, i3 UMR CNRS, 60 Bd St Michel, 75006 Paris, France

4 Office of Health Economics, 7th Floor, 105 Victoria St, Westminster, London SW1E 6QT, UK

\section{Key Points for Decision Makers}

Price regulation is related negatively to R\&D intensity, cash flow and profitability when firm effects are unaccounted for.

Firm differences and strategies are important in explaining the negative relationship between price regulation and $R \& D$ intensity.

Cash flow and profitability of European- and US-based firms respond differently to price regulation. 
place across Europe are based on reference pricing (external and internal) and value-based pricing [4]. While external reference pricing sets prices using the average price of a select basket of countries, which are used as references, internal reference pricing sets the price according to the price of other similar products within the country [4]. Value-based pricing on the other hand considers the value or the benefits of the product. European countries either employ one of the above pricing mechanisms or a combination of these-external reference pricing remains the most extensively used strategy. Prices of pharmaceuticals in the USA, in contrast, are not directly regulated, i.e. companies can freely set prices $[5,6]$. However, the usage of formularies of preferred drugs by patients and physicians has led to an increase in demand elasticity thereby allowing discounted prices for pharmacy-based managers and Medicaid [7]. In general, however, the US market remains largely unregulated.

The justification for regulating pharmaceutical prices is straight forward-it reduces drug prices and thereby curbs increasing pharmaceutical expenditure. While price regulation reduces prices and therefore controls expenditures ceteris paribus, it can also reduce companies' willingness to innovate and invest in research and development (R\&D) $[8,9]$. Thus, a trade-off exists between affordability of pharmaceutical products today and the necessity to incentivize pharmaceutical firms to provide new and better drugs in the future; an activity that plethora of studies suggest to be highly correlated with their profitability levels [10-14]. If profitability determines future $R \& D$ intensity and innovation, then price regulation will affect $R \& D$ of pharmaceutical companies through profitability. In this paper, we examine this link between price regulation and $R \& D$ intensity and investigate the role of cash flow and profitability as intermediate mechanisms.

We assessed the relationship between pharmaceutical research intensity (measured as the ratio of $R \& D$ expenditure to total sales) and price regulation, exploiting stylized facts about sales volumes in Europe and USA that give rise to variation in exposure to price regulation [15]. The earliest paper on this subject by Grabowski [10] concluded that R\&D spending decisions are sensitive to government policies affecting financial incentives of firms. Precisely, price regulation reduced $R \& D$ through expected profitability and flow of funds. While Grabowski [10] included three industries in the analysis, one of which was the drug industry, later studies focused exclusively on the pharmaceutical industry in different contexts exploiting specific institutional features. Grabowski and Vernon [12] used a pooled sample of 11 major US drug firms from 1994 to 1997 and found that expected returns and cash flows are important for pharmaceutical R\&D. Vernon [16] on the other hand, used data from 1987 to 1998 for 15 of Japan's largest firms and found results similar to the unregulated US market for pharmaceuticals; expected returns were an important determinant of R\&D expenditure in Japan. Vernon [15] exploited the fact that firms that sell more outside the USA are exposed to greater price regulation than those that sell more within the USA. He found that lagged cash flows and profit expectations are important determinants of R\&D investment. Our measure of price regulation is similar to that used by Vernon.

Others directly assessed the relationship between price regulation and R\&D expenditure. Golec and Vernon [17] used EU and US pharmaceutical real-price indexes as proxies for price regulation and found that if the USA had employed similar price regulations to that in the EU, companies would have spent \$US12.67 billion less in R\&D. In another study, Golec et al. [18] exploited price controls due to the Clinton Administration's Health Security Act (HSA) 1993 and reported that price controls led firms to cut R\&D expenditure by as much as $\$ 1$ billion. Similarly, simulation exercises in the USA and EU settings have shown that $R \& D$ investment is sensitive to prices and price regulation could lead to a significant reduction in research spending $[9,19]$. The most recent study by Eger and Mahlich [20] that directly assessed the relationship between R\&D expenditure and pharmaceutical price regulation, concluded that pharmaceutical price regulation has a deteriorating effect on R\&D investment by firms; specifically, sales beyond 33\% generated from the European market lowered R\&D investments.

We revisited the relationship between pharmaceutical price regulation and $R \& D$ intensity using a similar framework as in Vernon [15], yet our analysis differs from Vernon and contributes to the existing literature in several ways. First, we used the latest available firm-level data (2000-2017) for the world's top ten pharmaceutical firms; the last known estimates from Eger and Mahlich [20] come from data that are at least a decade old (2000-2008). Given, that the pharmaceutical landscape is continuously evolving in terms of regulatory practices and drug development processes, using latest data and a longer time-series provides new insights. Moreover, the data we used include a period when regulatory pressures were at the peak and many countries started adopting price regulation methods. This generates substantial variation in our price regulation measure over time. Second, in most prior literature, either the link between price regulation and profitability or that between profitability and R\&D investment is investigated. ${ }^{1}$ In this paper, we examined the

\footnotetext{
${ }^{1}$ Eger and Mahlich [20] investigate the link between regulation and R\&D investment; however, they do not investigate the role of cash flow and profitability as intermediate mechanisms.
} 
Table 1 Pearson correlation coefficients between our variables of interests

\begin{tabular}{lllll}
\hline & R\&D intensity & Profit margin (EBIT) & Cash flow & $\begin{array}{l}\text { Share of } \\
\text { sales in } \\
\text { Europe }\end{array}$ \\
\hline R\&D intensity & & & \\
$p$ value & - & & \\
Profit margin (EBIT) & 0.2309 & - & \\
$p$ value & 0.09 & & - & \\
Cash flow & 0.2463 & 0.5818 & -0.3531 & - \\
$p$ value & 0.0017 & 0.0000 & 0.0000 & \\
Share of sales in Europe & -0.3052 & -0.2877 & & \\
$p$ value & 0.0000 & 0.0001 & \\
\hline
\end{tabular}

EBIT earnings before interest and tax, $R \& D$ research and development link between price regulation (measured by relative market share in EU/USA) and R\&D intensity, exploring the role of cash flow and expected profitability as possible mechanisms, thus providing a comprehensive picture. Third, we differentiated our paper in several analytical ways (a) by using a two-way fixed effects model that controls for firm-specific heterogeneity, which explains the relationship between price regulation and R\&D intensity; (b) by using a more flexible model that allows the slope of price regulation to vary across firms; and (c) by investigating the dynamics of price regulation by interacting it with year dummies.

\section{Methods}

\subsection{Data}

Panel data from 2000 to 2017 for the top ten pharmaceutical firms was compiled from different sources. Firms included in the analysis were Astra Zeneca PLC (UK), Bayer AG (DE), Eli Lilly \& Co. (USA), GlaxoSmithKline PLC (UK), Johnson \& Johnson (USA), Merck \& Co. (USA), Novartis AG (CH), Pfizer Inc. (USA), Hoffmann-La Roche AG $(\mathrm{CH})$, and Sanofi SA (FR). ${ }^{2}$ These ten companies are key players in terms of revenue and R\&D activity. For the year 2017, the value of the R\&D investments of these companies alone accounted for more than $50 \%$ of the total value of $R \& D$ investments on the top 50 pharmaceutical companies by revenue and R\&D spending [21].

Financial data were retrieved from the Fundamental Annual section of the Compustat database accessible through the Wharton Research Data Services (https://

\footnotetext{
${ }^{2}$ Headquarters of the firms are reported in parentheses-country ISO code: UK-United Kingdom; DE-Germany; USA-United States of America; CH-Switzerland; FR-France.
}

wrds-www.wharton.upenn.edu/demo/compustat/form/). These data were complemented with additional data on financials, sales volume in Europe and USA, and mergers collected from the annual financial statements and reports published by the companies and accessible through their websites. In some cases the data were partially expressed in different currencies other than US dollars (British Pound, Swiss Franc, Euro), these figures were all converted to US dollars by using the average yearly exchange rates provided by the Federal Reserve of the United States of America [22]. Variable description and sources are provided in detail in the supplementary material (Table A1).

\subsubsection{Outcome Variable}

The outcome variable of interest is R\&D intensity measured as the ratio of $R \& D$ expenditure to total sales. $R \& D$ expenditure was taken from Compustat and represents all costs incurred during the year that relate to the development of new products or services. Total sales refer to net sales that represent gross sales reduced by cash discounts, trade discounts, etc. We used the ratio of expenditure to total sales as suggested by Grabowski [10] since firms included in the analysis operate at different scales and scale effects invariably dominate in such an analysis.

\subsubsection{Independent Variable}

The degree of exposure to price regulation was captured using a similar strategy to that in Vernon [15]. Specifically, Vernon [15] argues that the USA is a largely unregulated market in terms of prices, as a result firms that sell proportionately more in the US market than in the non-US market are exposed to lower price regulation. In contrast, the European market is directly regulated in terms of pricing of drugs; different price regulations both on the supply and demand side have been introduced. Therefore, the share of sales of a firm in Europe relative 


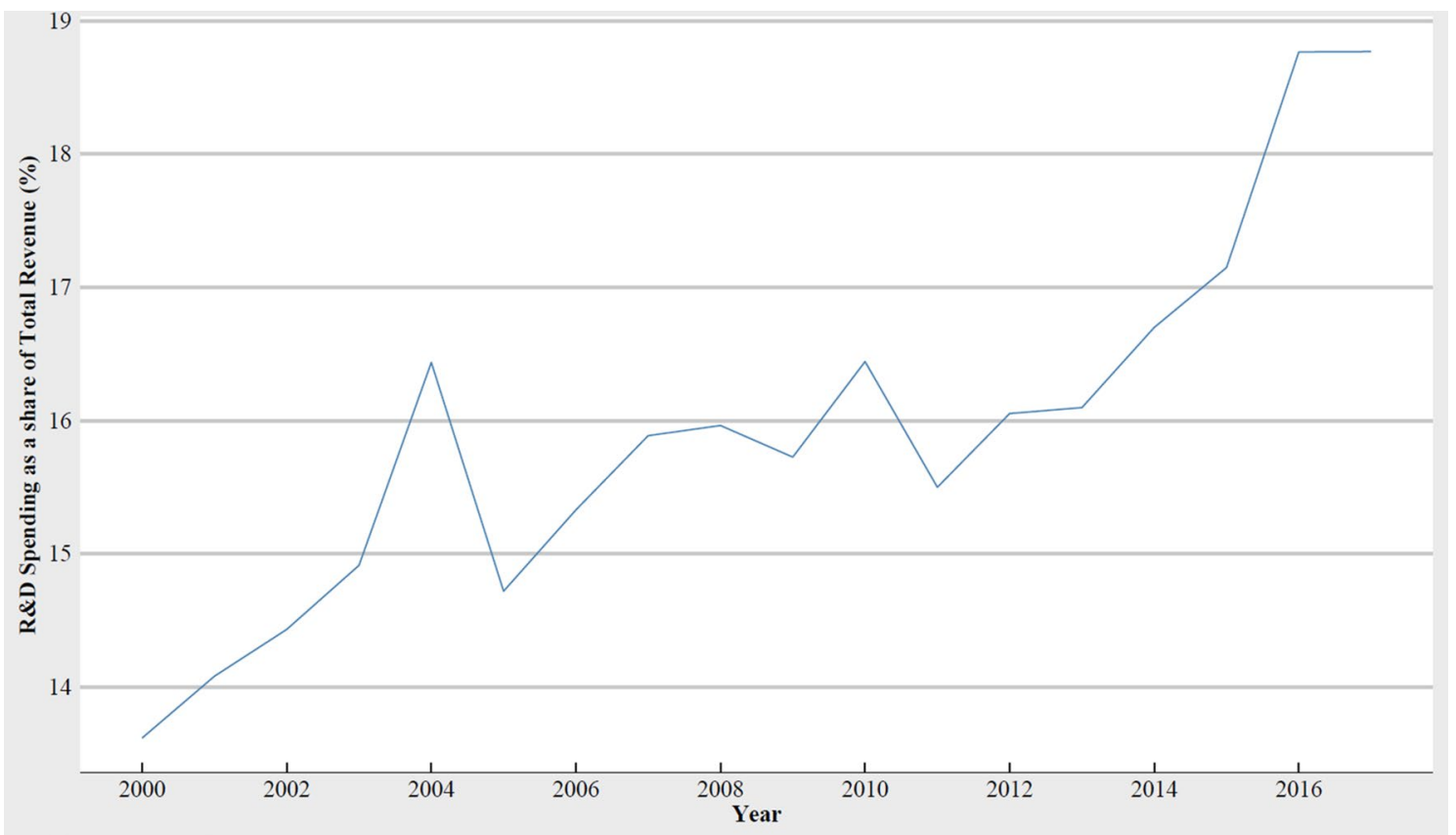

Fig. 1 Evolution of the sample mean R\&D intensity (R\&D spending as share of total revenue) from 2000 to 2017. Sources: own elaboration based on the WRDS Database and Companies Financial Statements. R\&D research and development, WRDS Wharton Research Data Services

to that in the USA is a plausible measure of exposure to price regulation. The data on the sales volume by region were collected from the financial and annual reports published by the firms.

\subsubsection{Intermediate Variables}

The intermediate variables, i.e. cash flow and profitability, were taken from the Compustat database and published annual reports of the firm. Cash flow was measured as the level of operating cash flow adjusted to the total revenue of the firm, while profitability was measured in terms of the profit margin, i.e. the level of earnings before interests and taxes (EBIT) adjusted to the total revenue of the firm.

\subsection{Descriptive Statistics}

For sake of exposition, we present the most pertinent descriptive findings here; however, complete summary statistics are presented in Table A2 in the supplementary material.

Figure 1 shows average R\&D intensity of the top ten firms in our sample. Overall, firms seem to have increased R\&D intensity from 2000 to 2017 . However, at the same time profit margins have remained relatively stable during this period (Fig. 2). Cash flow adjusted to sales increased steadily from 2000 to 2008; however, it decreased from 2008 to 2017. While the variation across years in cash flow and in profit margin seems minute, there is substantial variation in $R \& D$ intensity across years.

Figure 3 shows the share of sales in Europe relative to that in the USA. While the share of sales in Europe only slightly increased from 2000 to 2008 , they fell sharply from 2008 onwards until 2017. We also observe that European firms sell relatively more in Europe compared with US firms, a stylized fact reported in Vernon [15] and Eger and Mahlich [20].

Pearson correlations in Table 1 show a significant negative relation between share of sales in Europe and cash flow $(\rho=-0.3531 ; p$ value $=0.000)$, share of sales in Europe and profit margin $(\rho=-0.2877 ; p$ value $=0.0001)$, and share of sales in Europe and R\&D intensity $(\rho=-0.3052$; $p$ value $=0.000$ ) suggesting that price regulation (measured by relative market share in EU/USA) might negatively relate to R\&D intensity through cash flow and profitability. We also observe a weakly significant correlation between profit margin and R\&D intensity $(\rho=0.2309 ; p$ value $=0.09)$, and a significant positive correlation of cash flow with $R \& D$ intensity $(\rho=0.2463 ; p$ value $=0.0017)$ suggestive of the importance of cash flow for R\&D activity.

While the correlations provide a general idea about the associations, these should be treated as only suggestive. We explored these findings within a regression framework described next. 


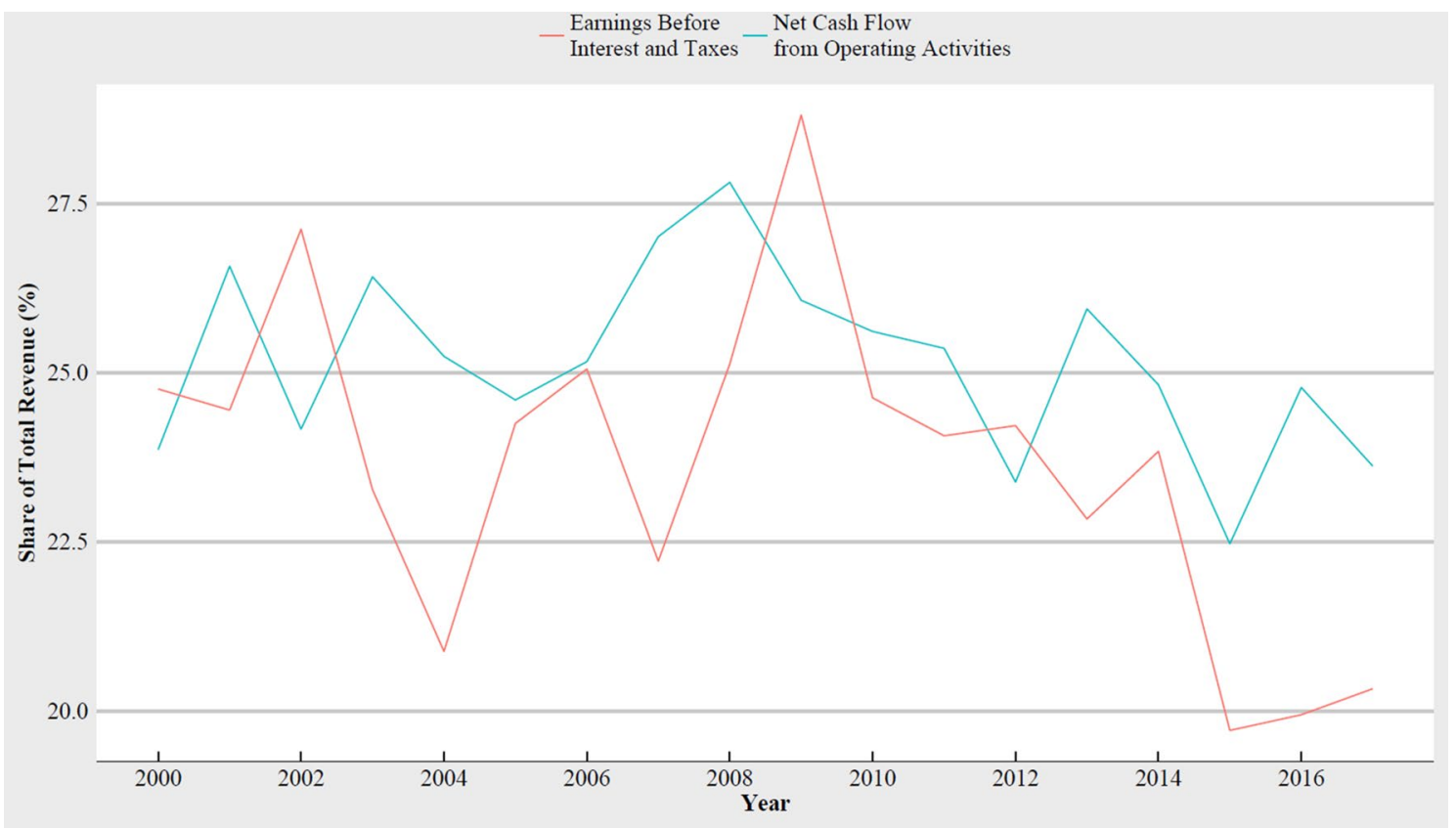

Fig. 2 Evolution of the sample mean net cash flow and earnings before interests and taxes (EBIT) expressed as share of total revenue from 2000 to 2017. Sources: own elaboration based on the WRDS Database and Companies Financial Statements. WRDS Wharton Research Data Services

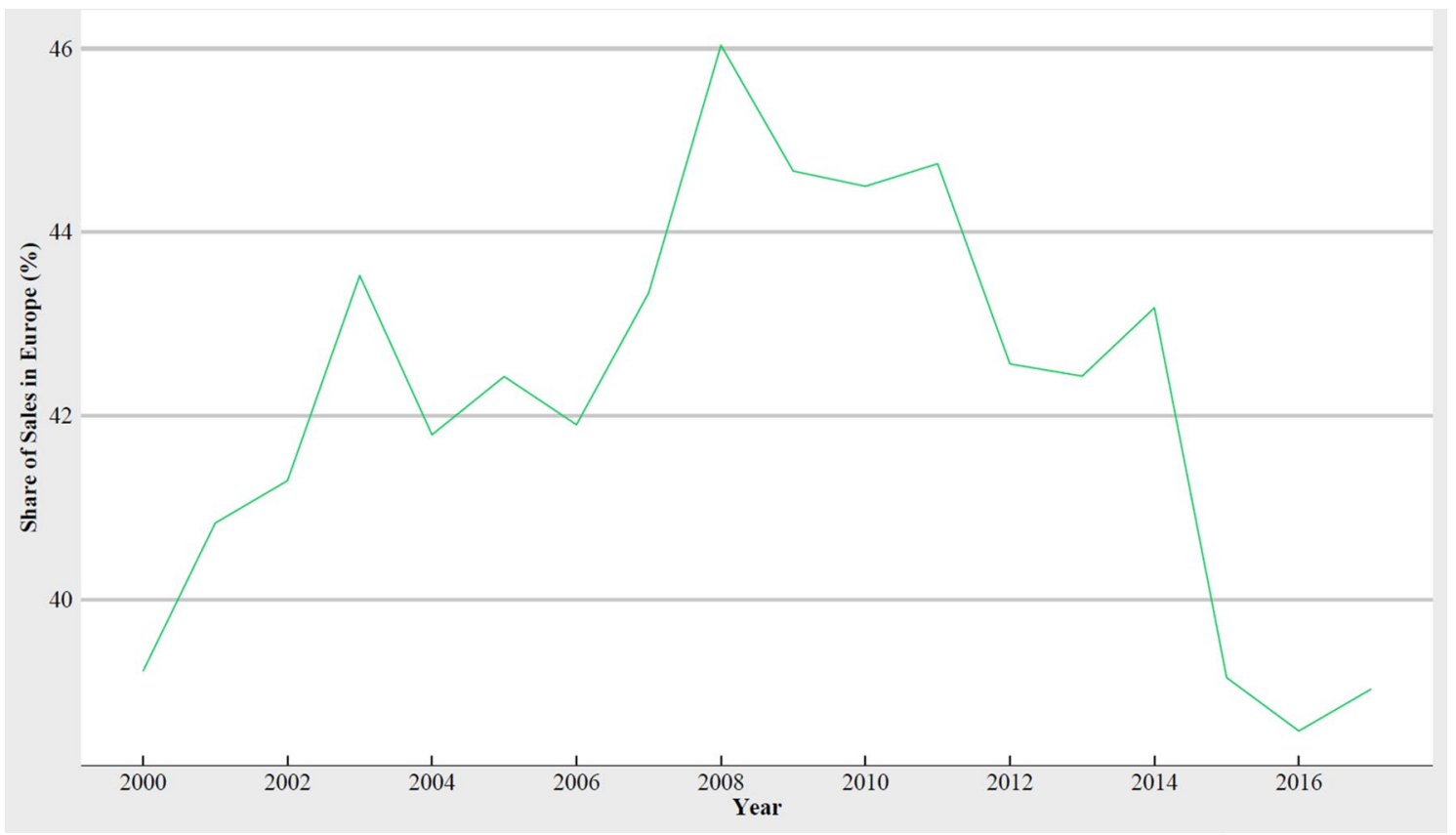

Fig. 3 Evolution of the sample mean share of sales in Europe relative to the share of sales in the USA from 2000 to 2017. Sources: own elaboration based on the WRDS Database and Companies Financial Statements. WRDS Wharton Research Data Services 


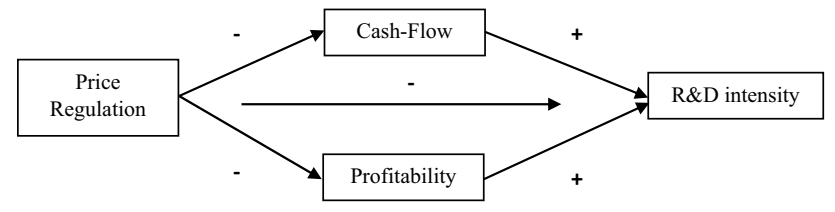

Fig. 4 Analytical framework-pharmaceutical price regulation and R\&D intensity

\subsection{Empirical Model}

We are interested in examining the link between price regulation and $R \& D$ intensity focusing on the role of cash flow and profitability as intermediary mechanisms. We adopt a framework similar to Vernon [15] as depicted in Fig. 4 below, ${ }^{3}$ where we hypothesize that (i) price regulation (measured by relative market share in EU/USA) relates negatively to cash flow and expected profitability; (ii) cash flow and profitability relate positively to R\&D intensity; and (iii) owing to (i) and (ii) price regulation (measured by relative market share in EU/USA) relates negatively to R\&D intensity.

Based on the framework in Fig. 4, we estimated the hypothesized relationships by means of ordinary least squares (OLS) regressions-specifically, we estimated three separate equations.

Equation 1 tests for the link between regulation at time $t$ and the intermediary variables i.e. cash flow and profitability at time $t$

$I M_{i t}=\alpha_{0}+\beta_{1}$ PriceRegulation $_{i t}+\gamma_{1} X_{i t}+\Omega_{i}+\rho_{t}+v_{i t}$,

where $i$ indexes firm and $t$ indexes year; $I M_{i t}$ refers to intermediary variables namely cash flow or profitability of firm $i$ in year $t$. PriceRegulation ${ }_{i t}$ is a measure of price regulation that firm $i$ faces in year $t$, as explained earlier; $X_{i t}$ is a vector of time varying firm level control variables namely mergers, acquisitions, and size of the firm proxied by number of employees. $\Omega_{i}$ corresponds to firm fixed effects and $\rho_{t}$ corresponds to year fixed effects. $v_{i t}$ refers to the error term in the equation.

Equation 2 below tests the link between intermediary variables at time $t-1$ above with $\mathrm{R} \& \mathrm{D}$ intensity at time t. Similar to Grabowski and Vernon [12] and Vernon [15], we used a 1-year lag of cash flow to explain R\&D intensity. Similarly, we also use 1-year lagged pre-tax profit margins as a reasonable proxy for expected profitability in the next year.

\footnotetext{
${ }^{3}$ Note that the framework in Fig. 4 is shown purely for sake of exposition; we did not adopt a structural modeling approach in the analysis.
}

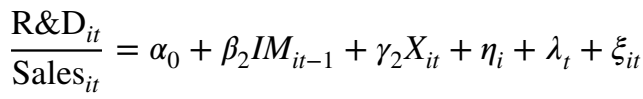

where $\frac{\mathrm{R} \& \mathrm{D}_{i t}}{\mathrm{Sales}_{i t}}$ refers to the R\&D intensity of firm $i$ in year $t$ and was measured as the ratio of R\&D expenditure to sales. $X_{i t}$ is a vector of time-varying firm level control variables similar to those used in Eq. (1), namely mergers, acquisitions, and size of the firm proxied by number of employees. $\eta_{i}$ corresponds to firm fixed effects and $\lambda_{t}$ corresponds to year fixed effects. $\xi_{i t}$ corresponds to the error term in the equation.

Finally, the relationship between pharmaceutical price regulation and R\&D intensity was estimated in Eq. 3 as follows:

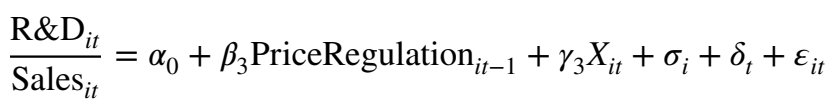

where $\frac{\mathrm{R} \& \mathrm{D}_{i t}}{\text { Sales }_{i t}}$ refers to the R\&D intensity of firm $i$ in year $t$ and was measured as the ratio of R\&D expenditure to sales. $X_{i t}$ is a vector of time-varying firm level control variables similar to that used in Eq. (1) namely mergers, acquisitions and size of the firm proxied by number of employees. $\sigma_{i}$ corresponds to firm fixed effects and $\delta_{t}$ corresponds to year fixed effects. $\varepsilon_{i t}$ is the usual error term.

While the above equations represent our final regression estimation strategy, to highlight the importance of firm fixed effects in R\&D investment decisions of firms, we first provide results of regressions that include only year fixed effects and then show the full results including year and firm fixed effects. Additionally, we conducted several robustness tests and explored further dynamics in different ways. Note that R\&D intensity, cash flow, and profitability are adjusted for total revenue of the firm. This is a common approach in the literature owing to the presence of heteroscedasticity when using absolute figures. Furthermore, scale effects tend to dominate in regression estimations when variables are correlated with size [10].

\section{Results}

\subsection{Main Results}

Table 2 shows results of Eqs. 1-3. The results displayed in this table include only year fixed effects and a set of control variables, namely mergers, acquisitions, and firm size.

Columns 1 and 2 show the relation between exposure to pharmaceutical price regulation (as measured by relative market shares EU/USA) and our intermediate variables, i.e. cash flow and expected profitability. As expected, higher exposure to pharmaceutical price regulation is negatively 
Table 2 Results of OLS regressions with year fixed effects

\begin{tabular}{|c|c|c|c|c|c|}
\hline Variables & $\begin{array}{l}\text { (1) } \\
\text { Cash flow }_{t}\end{array}$ & $\begin{array}{l}\text { (2) } \\
\text { Profitability }\end{array}$ & $\begin{array}{l}(3) \\
(\mathrm{R} \& \mathrm{D} / \mathrm{sales})_{\mathrm{t}}\end{array}$ & $\begin{array}{l}(4) \\
\left(\mathrm{R} \& \mathrm{D} / \text { sales }_{\mathrm{t}}\right.\end{array}$ & $\begin{array}{l}(5) \\
(\mathrm{R} \& \mathrm{D} / \text { sales })_{t}\end{array}$ \\
\hline $\begin{array}{l}\text { Exposure to price } \\
\text { regulation } \text { (as measured } \\
\text { by relative market shares } \\
\text { EU/US.) }\end{array}$ & $-0.267 * * *$ & $-0.274 * * *$ & - & - & - \\
\hline $\operatorname{Cash~flow~}_{(\mathrm{t}}-{ }_{1)}$ & - & - & $\begin{array}{l}0.171 * * * \\
(0.0408)\end{array}$ & - & - \\
\hline Profitability $_{(\mathrm{t}-1)}$ & - & - & - & $\begin{array}{l}0.104 * * * \\
(0.0351)\end{array}$ & - \\
\hline $\begin{array}{l}\text { Exposure to price } \\
\text { regulation }_{(\mathrm{t}-1)} \text { (as meas- } \\
\text { ured by relative market } \\
\text { shares EU/USA) }\end{array}$ & - & - & - & - & $(0.0212)$ \\
\hline Controls & Yes & Yes & Yes & Yes & Yes \\
\hline Year FE & Yes & Yes & Yes & Yes & Yes \\
\hline Constant & $\begin{array}{l}0.318 * \\
(0.170)\end{array}$ & $\begin{array}{l}0.509 * \\
(0.259)\end{array}$ & $\begin{array}{l}0.948 * * * \\
(0.0735)\end{array}$ & $\begin{array}{l}0.959 * * * \\
(0.0769)\end{array}$ & $\begin{array}{l}0.979 * * * \\
(0.0673)\end{array}$ \\
\hline Observations & 174 & 174 & 164 & 164 & 164 \\
\hline$R^{2}$ & 0.249 & 0.201 & 0.602 & 0.574 & 0.570 \\
\hline
\end{tabular}

Robust standard errors in parentheses. $E U$ Europe, $F E$ fixed effects, $O L S$ ordinary least squares, $R \& D$ research and development, USA United States of America

**** $p<0.01, * * p<0.05, * p<0.1$ associated with both current period cash flow and expected profitability, where the relationship on both is statistically significant at the $1 \%$ level. Columns 3 and 4 show the relationship between the intermediate variables and R\&D intensity. Both 1-year lagged cash flow and profitability are positively related to R\&D intensity and statistically significant at the $1 \%$ level. As hypothesized in the methodical framework in Fig. 4, since price regulation reduces cash flow and profitability, and both lagged cash flow and profitability increase R\&D intensity, we would expect lagged price regulation to therefore negatively relate to $R \& D$ intensity. Column 5 shows this expected result where the coefficient on price regulation is statistically significant at the $1 \%$ level and negatively related to $R \& D$ intensity. The results are qualitatively similar to those in Vernon [15] in terms of the sign of the coefficient.

Overall, the above OLS estimates suggest that while pharmaceutical price regulation (measured by relative market share in EU/USA) does affect R\&D intensity of firms, this effect operates through both cash flow and profitability.

While previous research could not effectively exploit within variation in the sample due to limited temporal data $[15,20]$, our 18-year long panel allows for within-firm estimations. Table 3 shows the results of estimations where both firm and year fixed effects are included. Including firm fixed effects in the analysis significantly raises the adjusted $R^{2}$ compared to Table 2 without firm fixed effects.

We continue to find a negative relationship between exposure to pharmaceutical price regulation (measured by relative market share in EU/USA) and both cash flow and expected profitability, significant at the $1 \%$ level (columns 1 and 2 of Table 3). While without firm fixed effects, in column 3 of Table 2, the relationship between cash flow and R\&D intensity was significant, in column 3 of Table 3 we do not find a significant relationship. Neither is expected profitability significantly related to $R \& D$ intensity (column 4 of Table 3). Expectedly, we also do not find a significant association between exposure to price regulation and $R \& D$ intensity itself as shown in column 5 of Table 3 . Although the point estimate itself remains unchanged (compare with column 5 of Table 1), the standard error increases rendering the statistical association insignificant. Table 3 also shows firm effects relative to the lowest revenue firm in our sample. All firm dummies are positive and highly significant for cash flow and profitability, while they are negative, and in general, highly significant for R\&D intensity.

Overall, the results suggest that the statistical relationship between profitability, cash flow, exposure to price regulation (measured by relative market share in EU/US) and R\&D intensity depends on the inclusion of firm fixed effects. This is not surprising given that prior research in 
Table 3 Results of OLS regressions with year and firm fixed effects relative to the lowest revenue firm

\begin{tabular}{|c|c|c|c|c|c|}
\hline Variables & $\begin{array}{l}\text { (1) } \\
\text { Cash flow }_{t}\end{array}$ & $\begin{array}{l}(2) \\
\text { Profitability }_{t}\end{array}$ & $\begin{array}{l}(3) \\
(\mathrm{R} \& \mathrm{D} / \mathrm{sales})_{\mathrm{t}}\end{array}$ & $\begin{array}{l}(4) \\
(\mathrm{R} \& D / \text { sales })_{\mathrm{t}}\end{array}$ & $\begin{array}{l}\text { (5) } \\
\left(\mathrm{R} \& \mathrm{D} / \text { sales}_{\mathrm{t}}\right.\end{array}$ \\
\hline $\begin{array}{l}\text { Exposure to price regulation } \text { (as }_{\mathrm{t}} \\
\text { measured by relative market } \\
\text { shares EU/USA) }\end{array}$ & $-0.346^{* * *}$ & $-0.418 * * *$ & - & - & - \\
\hline Cash flow $_{(t-1)}$ & - & - & $\begin{array}{l}0.0138 \\
(0.0407)\end{array}$ & - & - \\
\hline Profitability $_{(t-1)}$ & - & - & - & $\begin{array}{l}0.0129 \\
(0.0314)\end{array}$ & - \\
\hline $\begin{array}{l}\text { Exposure to price regulation } \\
\text { (as measured by relative mar- } \\
\text { ket shares EU/USA) }\end{array}$ & - & - & - & - & $(0.0495)$ \\
\hline \multicolumn{6}{|l|}{ Relative to lowest revenue firm } \\
\hline AstraZeneca (UK) & $\begin{array}{l}0.0678 * * \\
(0.0264)\end{array}$ & $\begin{array}{l}0.155 * * * \\
(0.0428)\end{array}$ & $\begin{array}{l}-0.0201 * * \\
(0.01000)\end{array}$ & $\begin{array}{l}-0.0208^{*} \\
(0.0108)\end{array}$ & $\begin{array}{l}-0.0328 * * \\
(0.0135)\end{array}$ \\
\hline Bayer (DE) & $\begin{array}{l}0.0399 \\
(0.0508)\end{array}$ & $\begin{array}{l}0.125 \\
(0.0821)\end{array}$ & $\begin{array}{l}-0.115^{* * *} \\
(0.0128)\end{array}$ & $\begin{array}{l}-0.116^{* * *} \\
(0.0103)\end{array}$ & $\begin{array}{l}-0.153 * * * \\
(0.0270)\end{array}$ \\
\hline GlaxoSmithKline (UK) & $\begin{array}{l}0.100 * * * \\
(0.0364)\end{array}$ & $\begin{array}{l}0.237 * * * \\
(0.0592)\end{array}$ & $\begin{array}{l}-0.0571 * * * \\
(0.0109)\end{array}$ & $\begin{array}{l}-0.0582 * * * \\
(0.0120)\end{array}$ & $\begin{array}{l}-0.0771 * * * \\
(0.0171)\end{array}$ \\
\hline Johnson \& Johnson (USA) & $\begin{array}{l}0.0571 * \\
(0.0328)\end{array}$ & $\begin{array}{l}0.175 * * * \\
(0.0548)\end{array}$ & $\begin{array}{l}-0.0798 * * * \\
(0.0122)\end{array}$ & $\begin{array}{l}-0.0810^{* * * *} \\
(0.0127)\end{array}$ & $\begin{array}{l}-0.0952 * * * \\
(0.0152)\end{array}$ \\
\hline Merck \& Co (USA) & $\begin{array}{l}0.0744 * * \\
(0.0287)\end{array}$ & $\begin{array}{l}0.135 * * * \\
(0.0438)\end{array}$ & $\begin{array}{l}-0.0203 * * \\
(0.00967)\end{array}$ & $\begin{array}{l}-0.0207 * * \\
(0.00986)\end{array}$ & $\begin{array}{l}-0.0297 * * \\
(0.0117)\end{array}$ \\
\hline Novartis $(\mathrm{CH})$ & $\begin{array}{l}0.142 * * * \\
(0.0439)\end{array}$ & $\begin{array}{l}0.230 * * * \\
(0.0688)\end{array}$ & $\begin{array}{l}-0.0299 * * * \\
(0.0111)\end{array}$ & $\begin{array}{l}-0.0302 * * * \\
(0.0112)\end{array}$ & $\begin{array}{l}-0.0568 * * * \\
(0.0214)\end{array}$ \\
\hline Pfizer (USA) & $\begin{array}{l}0.119 * * * \\
(0.0302)\end{array}$ & $\begin{array}{l}0.133 * * * \\
(0.0465)\end{array}$ & $\begin{array}{l}-0.0564 * * * \\
(0.0108)\end{array}$ & $\begin{array}{l}-0.0561 * * * \\
(0.0110)\end{array}$ & $\begin{array}{l}-0.0705^{* * *} \\
(0.0141)\end{array}$ \\
\hline Roche $(\mathrm{CH})$ & $\begin{array}{l}0.115 * * * \\
(0.0354)\end{array}$ & $\begin{array}{l}0.230 * * * \\
(0.0573)\end{array}$ & $\begin{array}{l}-0.0249 * * * \\
(0.00896)\end{array}$ & $\begin{array}{l}-0.0257 * * * \\
(0.00954)\end{array}$ & $\begin{array}{l}-0.0474 * * * \\
(0.0179)\end{array}$ \\
\hline Sanofi (FR) & $\begin{array}{l}0.132 * * * \\
(0.0426)\end{array}$ & $\begin{array}{l}0.212 * * * \\
(0.0667)\end{array}$ & $\begin{array}{l}-0.0456^{* * *} \\
(0.0102)\end{array}$ & $\begin{array}{l}-0.0458 * * * \\
(0.0101)\end{array}$ & $\begin{array}{l}-0.0738 * * * \\
(0.0197)\end{array}$ \\
\hline Controls & Yes & Yes & Yes & Yes & Yes \\
\hline Year FE & Yes & Yes & Yes & Yes & Yes \\
\hline Constant & $\begin{array}{l}0.754 * * * \\
(0.274)\end{array}$ & $\begin{array}{l}1.535 * * * \\
(0.475)\end{array}$ & $\begin{array}{l}0.305 * * * \\
(0.112)\end{array}$ & $\begin{array}{l}0.298 * * \\
(0.117)\end{array}$ & $\begin{array}{l}0.161 \\
(0.143)\end{array}$ \\
\hline Observations & 174 & 174 & 164 & 164 & 164 \\
\hline$R^{2}$ & 0.492 & 0.479 & 0.785 & 0.785 & 0.790 \\
\hline
\end{tabular}

Robust standard errors in parentheses. $C H$ Switzerland, $D E$ Germany, $E U$ Europe, $F E$ fixed effects, $F R$ France, $O L S$ ordinary least squares, $R \& D$ research and development, $U K$ United Kingdom, USA United States of America

${ }^{* * *} p<0.01, * * p<0.05, * p<0.1$ this area concludes similarly. Cockburn and Henderson [23] conclude that their results on pharmaceutical firms' productivity are not robust to the inclusion of firm fixed effects and that looking within the firm is important to understand the nuances of R\&D investment and success. Specifically, unobserved and difficult to measure firm specific distinctive competence and factors such as scientific expertise collected in-house and tacit knowledge about products, processes and markets that endow firms with competitive advantage could be important determinants of R\&D investment. While our results indeed endorse this view, we were unable to explore the role of such characteristics owing partly to limited data availability, but also due to the inherent difficulty in measuring such characteristics. 
Table 4 Robustness of OLS regressions with firm and year fixed effects with time lags

\begin{tabular}{|c|c|c|c|}
\hline Variables & $\begin{array}{l}(1) \\
(\mathrm{R} \& D / \text { sales })_{\mathrm{t}}\end{array}$ & $\begin{array}{l}(2) \\
(\mathrm{R} \& D / \text { sales })_{\mathrm{t}}\end{array}$ & $\begin{array}{l}(3) \\
(\mathrm{R} \& \mathrm{D} / \text { sales })_{\mathrm{t}}\end{array}$ \\
\hline Cash flow $(\mathrm{t}-2)$ & $\begin{array}{l}0.0291 \\
(0.0316)\end{array}$ & - & - \\
\hline Profitability $_{(\mathrm{t}-2)}$ & - & $\begin{array}{l}0.0298 \\
(0.0287)\end{array}$ & - \\
\hline $\begin{array}{l}\text { Exposure to price regulation }_{(\mathrm{t}-2)} \text { (as measured } \\
\text { by relative market shares EU/USA) }\end{array}$ & - & - & $\begin{array}{l}0.0537 \\
(0.0506)\end{array}$ \\
\hline \multicolumn{4}{|l|}{ Relative to lowest revenue firm } \\
\hline AstraZeneca (UK) & $\begin{array}{l}-0.0186^{*} \\
(0.0105)\end{array}$ & $\begin{array}{l}-0.0203^{*} \\
(0.0114)\end{array}$ & $\begin{array}{l}-0.0290 * * \\
(0.0141)\end{array}$ \\
\hline Bayer (DE) & $\begin{array}{l}-0.109 * * * \\
(0.0122)\end{array}$ & $\begin{array}{l}-0.110 * * * \\
(0.0108)\end{array}$ & $\begin{array}{l}-0.144 * * * \\
(0.0264)\end{array}$ \\
\hline GlaxoSmithKline (UK) & $\begin{array}{l}-0.0535 * * * \\
(0.0107)\end{array}$ & $\begin{array}{l}-0.0563 * * * \\
(0.0116)\end{array}$ & $\begin{array}{l}-0.0716^{* * * *} \\
(0.0169)\end{array}$ \\
\hline Johnson \& Johnson (USA) & $\begin{array}{l}-0.0750 * * * \\
(0.0121)\end{array}$ & $\begin{array}{l}-0.0775^{* * *} \\
(0.0123)\end{array}$ & $\begin{array}{l}-0.0918^{* * *} \\
(0.0157)\end{array}$ \\
\hline Merck \& Co (USA) & $\begin{array}{l}-0.0181 * \\
(0.00949)\end{array}$ & $\begin{array}{l}-0.0197 * * \\
(0.00975)\end{array}$ & $\begin{array}{l}-0.0235^{* *} \\
(0.0113)\end{array}$ \\
\hline Novartis $(\mathrm{CH})$ & $\begin{array}{l}-0.0247^{* *} \\
(0.0111)\end{array}$ & $\begin{array}{l}-0.0255^{* *} \\
(0.0114)\end{array}$ & $\begin{array}{l}-0.0479 * * \\
(0.0210)\end{array}$ \\
\hline Pfizer (USA) & $\begin{array}{l}-0.0529 * * * \\
(0.0108)\end{array}$ & $\begin{array}{l}-0.0523 * * * \\
(0.0108)\end{array}$ & $\begin{array}{l}-0.0681 * * * \\
(0.0144)\end{array}$ \\
\hline Roche $(\mathrm{CH})$ & $\begin{array}{l}-0.0206^{* *} \\
(0.00876)\end{array}$ & $\begin{array}{l}-0.0224 * * \\
(0.00922)\end{array}$ & $\begin{array}{l}-0.0397 * * \\
(0.0176)\end{array}$ \\
\hline Sanofi (FR) & $\begin{array}{l}-0.0421 * * * \\
(0.00990)\end{array}$ & $\begin{array}{l}-0.0430 * * * \\
(0.00984)\end{array}$ & $\begin{array}{l}-0.0674 * * * \\
(0.0201)\end{array}$ \\
\hline Controls & Yes & Yes & Yes \\
\hline Year FE & Yes & Yes & Yes \\
\hline Constant & $\begin{array}{l}0.354 * * * \\
(0.108)\end{array}$ & $\begin{array}{l}0.338 * * * \\
(0.110)\end{array}$ & $\begin{array}{l}0.203 \\
(0.148)\end{array}$ \\
\hline Observations & 157 & 157 & 154 \\
\hline$R^{2}$ & 0.784 & 0.785 & 0.793 \\
\hline
\end{tabular}

Robust standard errors in parentheses. $C H$ Switzerland, $D E$ Germany, $E U$ Europe, $F E$ fixed effects, $F R$ France, $O L S$ ordinary least squares, $R \& D$ research and development, $U K$ United Kingdom, USA United States of America

**** $p<0.01, * * p<0.05, * p<0.1$

\subsection{Additional Tests}

In this section we conducted additional analyses, in which we assessed the robustness of our results, and explored firm dynamics.

\subsubsection{Robustness Tests}

Vernon [15] and Grabowski [10] have empirically shown the effect of a one period lag of cash flow and profitability on R\&D intensity. We followed a similar approach in our analysis and lag cash flow and profitability by 1 year. However, it seems plausible to assess further delays in the relationship between cash flow, profitability, and R\&D intensity. Finkelstein [24] argues that it is not optimal to make current $R \& D$ decisions based on current policy due to long R\&D pipelines and uncertainty of future health policy. Therefore, it seems plausible that price regulation policies might also affect $R \& D$ with a longer delay. Given our sample size, we tested for 2-year lags of cash flow, profitability and price regulation and found similar results as before. Table 4 shows these results. Since the relationship between price 
regulation and both cash flow and profitability was tested contemporaneously in our model the results are similar to those in columns 1 and 2 of Table 3 . In Table 4 we directly show the results of the relationship between a two-period lag of cash flow, profitability, and exposure to price regulation with R\&D intensity. Columns 1, 2 and 3 show these results. The results are similar to those in Table 4, our main model, where we do not find a statistically significant association between any of these variables.

\subsubsection{Exploring Regulation-Firm Dynamics}

Factors such as firm size, technological know-how, scientific knowledge and process expertise accumulated in-house over time may provide firms with a distinct competitive advantage. Within the pharmaceutical industry, technological, marketing and regulatory competencies are particularly valuable $[25,26]$. Firms that have a higher level of such core competencies may be able to leverage unique skills when faced with regulatory hurdles and perform better than those firms with lower competencies. Thus, the effect of price regulation on cash flow and profitability and ultimately on R\&D intensity may vary across firms. We examined this by allowing for different coefficients of exposure to price regulation across firms by interacting firm dummies with our price regulation measure. The results of which are presented in supplementary material A3.

While overall, we find similar results as in Table 3, where exposure to price regulation (measured by relative market share in EU/USA) is negatively related to cash flow, profitability and R\&D intensity, we do find differences in the coefficient magnitudes across firms. Compared to the baseline estimates in Table 3 (column 1), coefficients of the relation between exposure to price regulation and cash flow are at least 2 to 3 times higher in magnitude where significant (column 1 of Table A3). Similarly, column 2 of Table A3 shows the coefficients of the relation between exposure to price regulation and profitability to be at least 3-4 times higher in magnitude across firms. Lagged cash flow and profitability are in general not significantly related to $R \& D$ intensity with some exceptions. Similarly, overall, for most firms, exposure to price regulation is mostly non-significant and negatively related to R\&D intensity (column 5 of Table A3) with the exception of some. Allowing the slope of exposure to price regulation to vary across firms also provides additional insights. Specifically, we can observe that all firms with headquarters in the USA show a negative relationship between exposure to price regulation and profitability (also for cash flow except for Pfizer). This pattern is less robust for firms with headquarters in Europe. We discuss this finding later.

\subsubsection{Exploring Regulation-Year Dynamics}

It is also likely that price regulation increases (decreases) with time with countries adopting more (less) regulatory measures over time. Countries in Europe adopted different price regulation measures at different times, thereby increasing (decreasing) the intensity of exposure to regulation, which is naturally reflected in our measure of price regulation (see Fig. 3). As a result of changing regulation, firms' business strategies and strategic choices may also evolve over time. We assessed this by interacting our exposure to price regulation measure with year dummies to allow the slope of price regulation to vary across years. The results are presented in Table A4 in the supplementary material. Exposure to price regulation shows a negative relationship with cash flow and profitability across all years (in some years, however, the coefficient is not statistically significant). Similarly, the relationship between cash flow and R\&D intensity, and profitability and R\&D intensity is positive but mostly non-significant. Overall, the results are similar to our main results in Table 3, i.e. we do not find a strong statistically significant relationship between exposure to price regulation (measured by relative market share in EU/USA) and R\&D intensity across years.

\section{Discussion}

The trade-off between affordability of drugs today and the necessity to incentivize pharmaceutical firms to engage in future R\&D to produce new and better drugs is well known. This paper revisited the relationship between pharmaceutical price regulation and $R \& D$ intensity by firms. We measured exposure to price regulation byexploiting the stylized fact that firms that sell more in Europe are exposed to greater price regulation than those that sell more in the USA, i.e. the share of sales of a firm in Europe relative to that in the USA is a plausible measure of price regulation. Adopting a similar framework as in Vernon [15], we estimated the relationship between this measure and R\&D intensity and explored the role of cash flow and profitability as intermediate mechanisms. ${ }^{4}$ To this end, we use the latest available data from 2000 to 2017 for the top 10 pharmaceutical companies and exploited variation between and within firms to assess how exposure to price regulation (measured by relative market share in EU/USA) relates to R\&D investment.

\footnotetext{
${ }^{4}$ While Vernon [15] used random effects models as his preferred specification, we did not use them since we believe that the firm specific effects correlate strongly with our other independent variables in the model. Random effects assumption could thus be violated.
} 
We find that firm fixed effects play a key role in explaining the negative association between exposure to price regulation and $R \& D$ found in prior studies. In OLS regression models without firm fixed effects, exposure to price regulation relates negatively to cash flow and profitability, and these latter variables relate negatively to R\&D. Expectedly, exposure to price regulation relates negatively to $R \& D$ indicating that cash flow and profitability are plausible channels for this finding. However, once firm fixed effects are included, while price regulation continues to relate negatively to cash flow and profitability, there is no significant relationship of price regulation with $R \& D$ intensity. This might suggest that big firms may not use their sales for financing their current or new R\&D pipeline, but instead, they may use them to recoup investments in existing products. More importantly, this result draws attention to the relevance of including firm specific effects in such an analysis. We include as controls, other important determinants of R\&D such as mergers and acquisitions, size of the firm, year fixed effects to account for common exogenous shocks, and region. Despite the inclusion of these variables, the coefficients lose significance only when firm fixed effects are included. This is unsurprising on two accounts. First, prior research in this area concludes similarly-Cockburn and Henderson [23] conclude that their results on pharmaceutical firms' productivity are not robust to the inclusion of firm fixed effects and that looking within the firm is important to understand the nuances of R\&D investment and success. Second, in an industry that limits imitation due to patents, resources, processes, and accumulated knowledge that are unique to the firm grant long-term competitive advantage [27]. To the extent that these correlate with firm specific effects, our findings are in line with the literature.

Our results are also consistent with the resource-based view within the strategic management and organizational science literature that has shown that firm effects strongly influence firm strategies and performance outcomes [28]. The role of unique firm resources and processes that endow competitive advantage is enhanced when firms are protected from imitation [27], which is particularly relevant in the pharmaceutical industry due to the existence of patent protection. The core resources within a pharmaceutical firm such as tacit knowledge and scientific expertise in drug development thus shape its strategic long-term irreversible decisions [29]. Henderson and Cockburn show that drug discovery is related to the expertise and competence of the firm in specific disciplines and disease areas. In addition, they find that the ability to maintain the flow of information in the firm's boundaries is another important determinant of productivity. Cockburn and Henderson in another study report that there is an important relationship between the diversity of the pharmaceutical firm's drug development trials and the success of each of the projects [23].
Additionally, we also explored firm and price regulation dynamics by allowing for different slopes of exposure to price regulation across firms and across the years in our sample. While the magnitude of the coefficients is different across firms and years, one interesting pattern emerges. Firms that are based in the USA (i.e. headquarters in the USA) show a negative relationship between price regulation and R\&D intensity. This finding does not hold robustly for European firms. Firms' locations are known to determine launch decisions and to influence prices. Therefore, location may play an important role in determining profitability and R\&D intensity. Kyle [30] explains, pharmaceutical firms have a home advantage in that governments may not apply price regulations in a similar manner across firms. Domestic firms could be favored and even compensated more than foreign firms by governments. In fact, firms may engage in $R \& D$ relevant to and profitable in their domestic market [30, 31]. In addition, domestic firms may receive significant tax benefits, approval application priorities and subsidies for engaging in domestically relevant research. The same may not apply for US-based firms that enter the European market and have a higher share of sales in Europe.

While we do not claim a causal relationship between price regulation and cash flow and profitability, and price regulation and $R \& D$, we are confident our results are driven by systematic variation between these variables. We controlled for the most important factors that have been consistently shown to influence firms' $R \& D$ investment decisions. Time variant confounders such as firm size, mergers, acquisitions, cash and asset equivalents, and time invariant confounders and common exogenous shocks to firms are all controlled for in our regression models. In separate regressions (not shown but available upon request) similar to those reported in Table 3, we directly controlled for region (Europe or USA) to which results remain robust. This allowed us to also control for other potential sources of heterogeneity between European and US markets, such as market access, regulatory approval, reimbursements, taxation and subsidy benefits, and even basic principles of health coverage at the system level.

Despite these, our study presents certain limitations. First, while we do control for different firm level variables and the region to show robustness, firms may still be exposed to different country level mandates with regard to industrial policies, regulations and reimbursement guidelines, which we were unable to test for due to unavailability of data at the firm-country level. Additionally, the characteristics of managers and CEOs that drive innovation may play an important role in R\&D decisions. Specifically, the extent to which firm fixed effects correlate with CEO or manager fixed effects could be examined. Future research can explore the impact of such variables with more granular data. Second, the variable of $R \& D$ expenditures captures the total amount of firm-sponsored $R \& D$, i.e. includes all $R \& D$ expenditure 
and not only investment for drug development. For example, it also captures additional expenses on software [21]. As a result, we may be overestimating $R \& D$ expenditure. However, since all firms in the data we use report R\&D in a similar manner, we can reasonably assume that it does not correlate with the independent variables and hence, despite the measurement error in our dependent variable, our OLS estimations have good properties [32]. Third, we explored lagged relationships by only up to 2 years; it is plausible that price regulation has a delayed effect, longer than the period we envisage and test in the paper. This remains an open avenue for further work with data on a larger number of firms. We were also unable to further explore the role of location in this paper due to the small number of firms we have. Data on more firms and more variation in headquarter locations could add additional insights on the role of firms' domestic versus foreign location in R\&D decisions. Finally, we did not examine welfare implications of our results, in that we made no attempt to assess how the gains by reducing pharmaceutical expenditures through price regulation offset the losses incurred by decreasing innovation and perhaps quality of medicines produced. Such an analysis will require extensive data on disease burden, drug consumption, pharmaceutical and other medical expenditures, and prices among other variables.

\section{Conclusions}

In this paper, we re-examined the relationship between pharmaceutical price regulation and $R \& D$ intensity using the latest (2000-2017) firm level data and explored the role of cash flow and profitability in mediating this relation. We find that exposure to price regulation as measured by relative market share in EU/USA is negatively associated with R\&D intensity, and this relationship is driven by the negative association of price regulation with cash flow and profitability. However, after the inclusion of firm fixed effects, while the negative association between price regulation, cash flow and profitability remain, that between price regulation and $R \& D$ intensity is no longer significant. We also find firm-level heterogeneity in these results, which may be partly associated with differences arising due to location of the firms. Our results provide new insights using recent firm level data and contribute to the sparse literature on this topic.

Acknowledgements Open Access funding provided by Projekt DEAL. We are grateful to the editor and to the three anonymous reviewers for several helpful comments that improved the manuscript substantially. Wharton Research Data Services (WRDS) was used in preparing this paper. This service and the data available thereon constitute valuable intellectual property and trade secrets of WRDS and/or its third-party suppliers.
Author Contributions MS and PDG conceptualized the paper. PDG led the data collection and DK contributed to the data collection during the revisions. MS, PDG and DK conducted the analysis, interpreted the results, and drafted the final version of the paper. All approved the final submitted version of the manuscript.

Data Availability Statement Firm level data on regional sales are available from the financial statements and annual reports of the respective firms and can be made available from the authors upon request. Remaining data that support the findings of this study are available from Wharton Research Data Services (WRDS) but restrictions apply to the availability of these data, which were used under institutional access for the current study, and so are not publicly available. The code used in the analysis is available upon request from the authors.

\section{Compliance with Ethical standards}

Funding This specific research did not receive grants from funding agencies in the public, commercial, or not-for-profit sectors.

Conflict of interest MS has previously provided consulting services to pharmaceutical companies on unrelated topics. PDG declare no conflict of interests. DK works at The Office of Health Economics, a registered charity and Independent Research Organization which receives funding from a variety of private and public sector sources.

Open Access This article is licensed under a Creative Commons Attribution-NonCommercial 4.0 International License, which permits any non-commercial use, sharing, adaptation, distribution and reproduction in any medium or format, as long as you give appropriate credit to the original author(s) and the source, provide a link to the Creative Commons licence, and indicate if changes were made. The images or other third party material in this article are included in the article's Creative Commons licence, unless indicated otherwise in a credit line to the material. If material is not included in the article's Creative Commons licence and your intended use is not permitted by statutory regulation or exceeds the permitted use, you will need to obtain permission directly from the copyright holder. To view a copy of this licence, visit http://creativecommons.org/licenses/by-nc/4.0/.

\section{References}

1. Galizzi MM, Ghislandi S, Miraldo M. Effects of reference pricing in pharmaceutical markets. Pharmacoeconomics. 2011;29(1):17-33.

2. Kessler DP. The effects of pharmaceutical price controls on the cost and quality of medical care: a review of the empirical literature. US Department of Commerce and International Trade Administration. 2004. https://www.citeseerx.ist.psu.edu/viewdoc/ download?doi=10.1.1.461.4648\&rep=rep1\&type=pdf. Accessed 20 Jan 2020

3. Danzon PM. Regulation of price and reimbursement for pharmaceuticals. In: The Oxford Handbook of the Economics of the Biopharmaceutical Industry; 2012.

4. Panteli D, Arickx F, Cleemput I, Dedet G, Eckhardt H, Fogarty E, Kaitelidou D. Pharmaceutical regulation in 15 European countries. Health Syst Transit. 2016;18(5):1-118.

5. Atella V, Bhattacharya J, Carbonari L. Pharmaceutical price controls and minimum efficacy regulation: evidence from the United States and Italy. Health Serv Res. 2012;47(1 pt 1):293-308. 
6. Sood N, De Vries H, Gutierrez I, Lakdawalla DN, Goldman DP. The effect of regulation on pharmaceutical revenues: experience in nineteen countries. Health Aff. 2008;27(Suppl 1):w125-w137137.

7. Danzon PM, Chao LW. Does regulation drive out competition in pharmaceutical markets? J Law Econ. 2000;43(2):311-58.

8. Dubois P, De Mouzon O, Scott-Morton F, Seabright P. Market size and pharmaceutical innovation. RAND J Econ. 2015;46(4):844-71.

9. Abbott TA, Vernon JA. The cost of US pharmaceutical price regulation: a financial simulation model of R\&D decisions. Manag Decis Econ. 2007;28(4-5):293-306.

10. Grabowski HG. The determinants of industrial research and development: a study of the chemical, drug, and petroleum industries. J Polit Econ. 1968;76(2):292-306.

11. Grabowski HG, Mueller DC. Industrial research and development, intangible capital stocks, and firm profit rates. Bell J Econ. 1978;9(2):328-43.

12. Grabowski HG, Vernon J. The determinants of pharmaceutical research and development expenditures. J Evol Econ. 2000;10(1-2):201-15.

13. Scherer FM. The link between gross profitability and pharmaceutical R\&D spending. Health Aff. 2001;20(5):216-20.

14. Giaccotto C, Santerre RE, Vernon JA. Drug prices and research and development investment behavior in the pharmaceutical industry. J Law Econ. 2005;48(1):195-21414.

15. Vernon JA. Examining the link between price regulation and pharmaceutical R\&D investment. Health Econ. 2005;14(1):1-16.

16. Vernon JA. The relationship between price regulation and pharmaceutical profit margins. Appl Econ Lett. 2003;10(8):467-70.

17. Golec J, Vernon JA. Financial effects of pharmaceutical price regulation on R\&D spending by EU versus US firms. Pharmacoeconomics. 2010;28(8):615-28.

18. Golec J, Hegde S, Vernon JA. Pharmaceutical R\&D spending and threats of price regulation. J Financ Quant Anal. 2010;45(1):239-64.

19. Bardey D, Bommier A, Jullien B. Retail price regulation and innovation: reference pricing in the pharmaceutical industry. J Health Econ. 2010;29(2):303-16.
20. Eger S, Mahlich JC. Pharmaceutical regulation in Europe and its impact on corporate R\&D. Health Econ Rev. 2014;4(1):23.

21. WRDS-Database. Compustat Fundamentals Annual and Quarterly. 2018. https://www.wrdsweb.wharton.upenn.edu/wrds/. Accessed 20 Jan 2020.

22. FED. Foreign Exchange Rates, Federal Reserve of the United States of America. 2020. https://www.federalreserve.gov/relea ses/g5a/current/. Accessed 20 Jan 2020.

23. Cockburn IM, Henderson RM. Scale and scope in drug development: unpacking the advantages of size in pharmaceutical research. J Health Econ. 2001;20(6):1033-57.

24. Finkelstein A. Static and dynamic effects of health policy: evidence from the vaccine industry. Q J Econ. 2004;119(2):527-64.

25. Henderson R, Cockburn I. Measuring competence? Exploring firm effects in pharmaceutical research. Strateg Manag J. 1994;15(S1):63-84.

26. Bogner WC, Thomas H. Core competence and competitive advantage: a model and illustrative evidence from the pharmaceutical industry. In: Hamel G, Heene A, editors. Competence-based competition. Chichester: John Wiley \& Sons; 1994. p. 111-44.

27. Lippman, SA, Rumelt, RP. Uncertain imitability: an analysis of interfirm differences in efficiency under competition. Bell J Econ. 1982; 418-438.

28. Mauri AJ, Michaels MP. Firm and industry effects within strategic management: an empirical examination. Strateg Manag J. 1998;19(3):211-9.

29. Ghemawat P. Commitment: the dynamic of strategy. New York: Free Press; 1991.

30. Kyle MK. Pharmaceutical price controls and entry strategies. Rev Econ Stat. 2007;89(1):88-99.

31. Kyle MK. The role of firm characteristics in pharmaceutical product launches. Rand J Econ. 2007;37(3):602-18.

32. Wooldridge JM. Introductory econometrics: a modern approach. Oxford: Nelson Education; 2016. 